\title{
Fenomena Cashless Society pada Generasi Milenial dalam Menghadapi Covid-19
}

\author{
Dini Haryati, S.E., M.Ak \\ IAI Nusantara Batanghari Muara Bulian \\ diniharyati14@gmail.com
}

\begin{abstract}
The millennial generation is a generation that was born between the 1980s and the present. This generation is very familiar with the world of digital-based technology. The use of gadgets is part of their lifestyle. The number of social media users among millennials is quite large, reaching 93\%. Moreover, at this time, the risk of being infected with the corona virus in financial transactions is a direct concern of the public in every purchasing activity. So that people prefer to use contactless financial transactions by making payments through digital wallet applications. This study aims to determine the phenomenon of cashless society in the millennial generation in dealing with Covid-19. In this study, the researcher chose to use a qualitative research type. Data collection techniques were carried out by interview, non-participant observation method on 15 key informants of students of the Batanghari Nusantara Islamic Institute. The results showed that most people, especially millennials, used the OVO, Shopee, Link Aja, Dana and other applications during the Covid-19 pandemic. By using a payment instrument like this it makes it easier for public services to reduce the risk of being infected with the corona virus.
\end{abstract}

Keywords: Cashless Society, Student Lifestyle, Millennial, Digital Wallets, Covid-19

\begin{abstract}
Abstrak- Generasi milenial adalah sebuah generasi yang lahir antara tahun 1980an sampai sekarang. Generasi ini amat akrab dengan dunia teknologi berbasis digital. Penggunaan gadget merupakan bagian dari lifestyle mereka. Jumlah pengguna media sosial dikalangan milenial ini cukup besar yakni mencapai 93\%. Apalagi pada saat ini adanya resiko terinfeksi virus corona dalam bertransaksi keuangan secara langsung menjadi kekhawatiran masyarakat dalam setiap aktivitas pembelian. Sehingga masyarakat lebih memilih menggunakan transaksi keuangan tanpa kontak dengan melakukan pembayaran melalui aplikasi dompet digital. Penelitian ini bertujuan untuk mengetahui fenomena cashless society pada generasi milenial dalam mengadapi covid-19. Pada penelitian ini, peneliti memilih menggunakan tipe penelitian kualitatif. Teknik pengumpulan data dilakukan dengan wawancara, metode observasi non-partisipan pada 15 key informant mahasiswa Institut Agama Islam Nusantara Batanghari. Hasil penelitian menunjukan bahwa sebagian besar masyarakat khususnya dikalangan milenial menggunakan aplikasi OVO, Shopee, Link Aja, Dana dan lainnya selama masa pandemi covid-19 ini. Dengan menggunakan alat pembayaran seperti ini lebih memudahkan layanan masyarakat sehingga mengurangi resiko terinfeksi virus corona.
\end{abstract}

Kata kunci : Cashless Society, Gaya Hidup Mahasiswa, Milenial, Dompet Digital, Covid-19

\section{PENDAHULUAN}

Perkembangan sistem pembayaran berinovasi dari tahun ke tahun dampak dari kemajuan teknologi informasi, seiring dengan kemajuan sistem digitalisasi jasa keuangan dan instrumen-instrumen transaksi pembayaran. Inovasi sistem pembayaran pada awalnya sistem manual/konvensional harus membawa fisik uang dan ikut antrian di loket pembayaran bank, kemudian berinovasi menjadi sistem pembayaran dengan instrumen non tunai memakai APMK (Alat Pembayaran Menggunakan Kartu) seperti kartu ATM/Debet dan kartu kredit, kini telah bertransformasi dengan inovasi terbaru yaitu digitalisasi sistem pembayaran dengan model uang elektronik (e-electronic).
Dimasa Pandemi ini juga telah mengubah habit masyarakat atau perilaku masyarakat dalam bertransaksi secara nontunai dengan menggunakan dompet digital atau $e$-wallet agar mengurangi resiko terinfeksi virus corona yang menempel pada uang, kartu kredit atau tangan orang yang menyerahkan atau menerima uang tersebut. World Health Organization (WHO) mengimbau masyarakat agar dapat menerapkan contactless payment. Contactless payment dimaksudkan disini adalah mengurangi kontak dengan pembayaran tunai dengan menggunakan dompet digital atau transaksi elektronik (Anonim, 2020).

Transformasi transaksi pembayaran secara elektronik terdiri dari beberapa model, antara lain; transfer langsung (electronic funds 
transfer), menggunakan kartu pembayaran (payment card), menggunakan uang elektronik (electronic money) dan uang digital (digital money). Perbedaan model penyimpanan nilai uang digitalisasi dengan uang elektronik yaitu dalam uang digital tidak memiliki nilai instrinsik dan tidak berwujud diterbitkan sebagai pengganti uang konvensional, dapat berdiri sendiri dan penerbitannya tidak berdasarkan pada uang konvensional, sedangkan uang elektronik bentuk uang tanpa uang fisik (cashless money) yang menyimpan nilai uang dalam bentuk data digital. Hal ini berbeda juga dengan APMK, dengan kartu ATM/Debit, nilai uang disimpan dalam rekening pemilik kartu.

Perubahan sistem pembayaran ini berkembang semakin pesat mengikuti perkembangan teknologi, hal ini membuat adanya perubahan gaya hidup (life style) dalam tatanan masyarakat yang dulunya bertransaksi menggunakan uang tunai sekarang digantikan oleh uang elektronik (e-money).

Uang elektronik (e-money) pertama kali diterbitkan di Indonesia pada bulan April 2007. Sejak pertama kali diterbitkan oleh Bank Indonesia, e-money menawarkan

beberapa keuntungan bagi para penggunanya dan bagi Bank Indonesia. Beberapa manfaat atau kelebihan dari penggunaan e-money dibandingkan dengan uang tunai maupun alat pembayaran non-tunai lainnya adalah memberikan kemudahan dalam transaksi pembayaran secara cepat dan aman bagi masyarakat luas, masalah cash handling yang selama ini sering dialami ketika menggunakan uang tunai sebagai pembayaran dari industri dapat dipecahkan, meningkatkan efisiensi percetakan uang dan penggandaan uang bagi bank Indonesia.

Perkembangan uang elektronik di Indonesia terbilang cukup cepat dibandingkan dengan perkembangan negara-negara berkembang lainnya. Indonesia sendiri sudah melakukan sosialisasi bagi penggunaan uang eletronik berbasis teknologi sejak tahun 2006. Hal ini awalnya sebagai penunjang sosialisasi redenominasi uang rupiah namun kemudian dikembangkan menjadi sebuah gerakan bernama Gerakan Nasional Nontunai (GNNT) yang resmi dicanangkan pada 14 Agustus 2014 lalu. Bahkan uang elektronik sudah menjalar ke berbagai instansi pendidikan.

Di dunia pendidikan aplikasi e-money biasa diterima dalam bentuk kartu mahasiswa, ataupun kartu khusus yang dapat digunakan untuk melakukan transaksi di wilayah institusi terkait. Meskipun e-money telah diintergrasikan dengan kartu mahasiswa penggunaannya masih rendah. Hal ini terjadi disebabkan oleh kurangnya informasi mengenai produk e-money yang digunakan dan tidak adanya sikap terbuka dari mahasiswa. Dibandingkan dengan e-money, mahasiswa lebih menyukai pemakaian uang elektronik menggunakan dompet digital berbasis internet yang dapat digunakan secara luas contohnya seperti Ovo, T-cash, Paytren, Danaku, atau Go-Pay. Go-Pay merupakan layanan aplikasi uang elektronik yang terpopuler serta paling banyak diminati oleh publik. Berdasarkan survey yang dilakukan Jakpat dan OJK pada tahun 2020 terhadap 825 responden, Gopay menempati pemakai tertinggi dengan jumlah persentase $79,39 \%$.

Pengguna Uang Elektronik

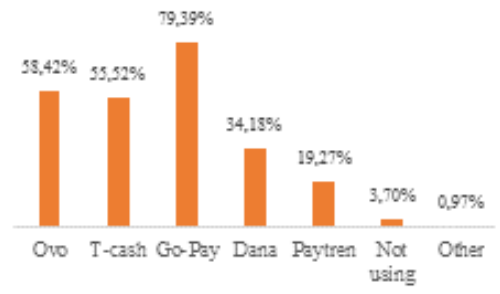

Diagram 1.1 Data Survey Pengguna Fintech EMoney Jakpat dan OJK, 2020.

Cashless society adalah sebutan yang merujuk pada masyarakat yang dalam bertransaksi, tidak lagi menggunakan uang fisik, melainkan melalui perpindahan informasi finansial secara digital. Dalam bertransaksi sehari-hari, masyarakat tidak menggunakan uang nyata, melainkan uang digital (Bintarto, 2018). Dompet digital adalah jenis akun prabayar yang dilindungi dengan kata sandi di mana pengguna dapat menyimpan uang untuk setiap transaksi online, seperti pembayaran untuk makanan, 
belanja barang online, dan tiket penerbangan. Dompet digital bisa di unduh secara gratis melalui smartphone setiap orang (Rosmayanti, 2019). Dompet digital telah menjadi bagian dari kehidupan sehari-hari masyarakat dimana dalam waktu seminggu sekitar satu hingga dua kali menggunakan pembayaran transaksi mencapai $68 \%$.

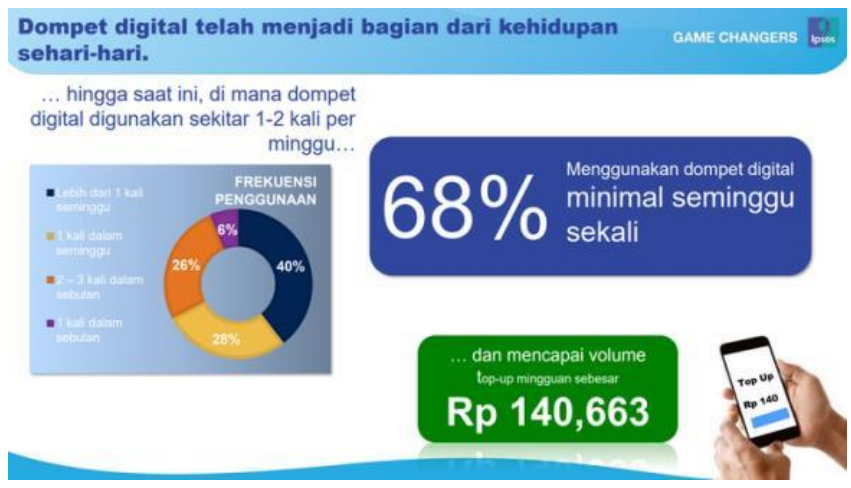

Sumber:

https://nextren.grid.id(Prama, 2020)

\section{Gambar 1. Dompet Digital Menjadi Kehidupan Sehari-hari}

Adanya dompet digital seperti OVO, Gopay, Dana, Linkaja menjadikan manusia konsumtif dikarenakan mudahnya layanan transaksi melalui digital. Transaksi yang paling sering digunakan menurut hasil riset lembaga riset berbasis aplikasi, snapchart yaitu transaksi retail $(28 \%)$, pemesanan transportasi online (27\%), dan pemesanan makanan online (20\%). Sisanya, untuk transaksi e-commerce (15\%) dan pembayaran tagihan (7\%). Segmen transaksi pemesanan transportasi online dan pengiriman makanan online, data penelitian Snapcart menunjukkan posisi ovo sebagai dompet digital layanan Grab dan Grab Food menunjukkan 71\% responden yang menggunakan OVO untuk transaksi ini (sutriyanto, 2019).

Berdasarkan data di atas dapat dikatakan bahwa uang elektronik untuk transaksi harian seperti transportasi, pengiriman makanan cepat saji, dan belanja telah popular di kalangan konsumen Indonesia terutama pada kaum generasi milenial maupun generasi $\mathrm{Z}$ yang dikenal fasih menggunakan teknologi. Bagi generasi milenial, sudah menjadi hal yang biasa berbelanja atau bertransaksi tanpa uang tunai. Mereka sudah terbiasa menggunakan alat-alat elektronik seperti kartu debit, kredit, ataupun uang elektronik (Rif'ah, 2019). Maraknya penggunaan dompet digital di kalangan generasi milenial menjadikan ketertarikan peneliti dalam hal memanfaatkan teknologi kekinian (uang elektronik) dari motif dan interaksi.

Banyaknya dompet digital yang ada di Indonesia peneliti hanya mengambil OVO dan ShopeePay sebagai objek penelitian sedangkan subjek penelitiannya yakni mahasiswa Institut Agama Islam Nusantara Batanghari yang termasuk ke rentang usia generasi milenial. Adapun rentang usia generasi milenial diantara tahun 1980 hingga tahun 2000. Mereka disebut generasi milenial karena merekalah generasi yang hidup di pergantian milenium (Yuswohady, 2016).

Shopeepay adalah sebuah metode pembayaran virtual yang telah disediakan shopee, dimana untuk bisa menggunakannya pembeli harus isi saldo terlebih dahulu.Jika saldo mencukupi maka anda bisa pilih shopeepay sebagai alat pembayaran terhadap pesanan yang kamu lakukan. Apalagi disaat pandemi seperti ini pasti rata-rata kaum milenial menggunakan aplikasi ini.

OVO adalah sebuah aplikasi smart memberikan layanan pembayaran dan transaksi secara online (OVO Cash), juga bisa berkesempatan untukmengumpulkan poin setiap kali melakukan transaksi pembayaran melalui OVO. OVO cash dapat digunakan untuk berbagai macam pembayaran yang telah bekerja sama dengan ovo menjadi lebih cepat. (www.ovo id./faq). Ovo mendapatkan predikat sebagai top of mind kategori dompet digital dari masyarakat sebesar $45 \%$.
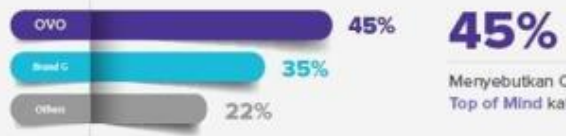


\section{Gambar 2. OVO Sebagai Top Of Mind Dompet Digital}

Sumber: https://www.tribunnews.com

\section{METODE PENELITIAN}

Penelitian ini menggunakan pendekatan kualitatif, dengan pendekatan fenomenologi. Fenomenologi dapat diartikan pengalaman subjektif atau pengalaman fenomenologikal. Pandangan berfikir yang menekankan pada fokus pengalaman-pengalaman subjektif manusia dan interpretasi dunia (Moleong, 2006).

Pemilihan informasi dengan teknik purposive sampling, yaitu teknik sampling yang menggunakan kriteria terpilih oleh peneliti dalam memilih sampel. Kriteria informasi yang dipilih dengan menggunakan pertimbangan tertentu yang sesuai dengan ciri-ciri spesifik yang dimilikinya (Nasution, 2006, p. 98).

Penelitian ini yang menjadi sampel adalah mahasiswa Institut Agama Islam Nusantara Batanghari. Jumlah mahasiswa Institut Agama Islam Nusantara Batanghari yakni 885 orang dari angkatan 2017-2020. Dalam penelitian ini digunakan perhitungan sampel menurut Rumus Slovin (Sugiyono, 2011:37):

Berdasarkan rumus di atas maka didapatkan jumlah sampel 90 orang. Jumlah sampel 90 kemudian peneliti menentukan kriteria dari 90 tersebut untuk dijadikan sebagai sampel yang memenuhi kriteria dari peneliti. Adapun kriteria yang dijadikan sebagai sampel penelitian yaitu:

1. Informan yang usianya termasuk ke dalam generasi milenial yaitu antara tahun 1980-2000,

2. Informan yang aktif menggunakan aplikasi OVO untuk keperluan seharihari (menggunakan transportasi online)

3. Informan yang melakukan pembelian makanan dan minuman online melalui aplikasi grabfood,

4. Informan yang mencari promo atau diskon.

5. Informan yang melakukan belanja online melalui aplikasi Shopee dan membayarnya menggunakan Shopeepay.
Pengumpulan data dilakukan dengan metode observasi non-partisipan, wawancara mendalam yang merupakan wawancara tidak terstruktur, dan dokumentasi.

Tabel 1: Hasil Purposive Sampling

\begin{tabular}{|c|c|}
\hline Kriteria Sampel & Jumlah \\
\hline Hasil yang didapatkan dari rumus Slovin & 90 \\
\hline $\begin{array}{l}\text { Pengurangan Sampel Kriteria 1: } \\
\text { Informan yang usianya termasuk ke } \\
\text { dalam generasi milenial yaitu antara tahun } \\
\text { 1980-2000 }\end{array}$ & 3 \\
\hline $\begin{array}{l}\text { Pengurangan Sampel Kriteria 2: } \\
\text { Informan yang aktif menggunakan } \\
\text { aplikasi OVO untuk keperluan sehari-hari } \\
\text { menggunakan transportasi online }\end{array}$ & 20 \\
\hline $\begin{array}{l}\text { Pengurangan Sampel Kritera 3: } \\
\text { Informan yang melakukan pembelian } \\
\text { makanan dan minuman online melalui } \\
\text { aplikasi grabfood }\end{array}$ & 22 \\
\hline $\begin{array}{l}\text { Pengurangan Sampel Kriteria 4: } \\
\text { Informan yang mencari promo atau } \\
\text { diskon. }\end{array}$ & 15 \\
\hline $\begin{array}{l}\text { Pengurangan Sampel Kriteria 5: } \\
\text { Informan yang melakukan belanja online } \\
\text { melalui aplikasi Shopee dan } \\
\text { membayarnya menggunakan Shopeepay. }\end{array}$ & 10 \\
\hline Jumlah & 20 \\
\hline
\end{tabular}

\section{HASIL DAN PEMBAHASAN}

Hasil yang ditemukan di lapangan berdasarkan wawancara dengan nara sumber yakni motif dan interaksi yang dilakukan generasi milenial dalam menggunakan dompet digital OVO berbeda-beda. Berdasarkan hasil wawancara terhadap key informant maka dapat dianalisis antara hubungan konsep diri dengan motivasi penggunaan internet. Beberapa penuturan yang didapat sangat terlihat jelas bahwa penggunaan aplikasi dompet digital OVO berada pada motivasi shopping dan relaxation. Faktor shopping terdiri dari mendapatkan informasi tentang barang dan membeli produk yang diinginkan, sedangkan faktor relaxation terdiri dari memesan sesuatu lebih cepat, merasa lebih nyaman dan aman ketika bertransaksi, tidak merasa khawatir terhadap keuangan dan 
mempermudah pembayaran. Ketika seseorang sudah ditahap termotivasi maka ia tidak bisa menahannya untuk melakukan perilaku konsumtif.

Peneliti menganalisis dari sisi motif mahasiswa yang termasuk generasi milenial ada 3 motif: Pertama, faktor promo atau diskon atau cashback yang diberikan OVO. Motif dalam memburu promo yang dialami oleh generasi milenial dalam menggunakan aplikasi ovo pernah dialami. Beberapa diantara mereka menyatakan bahwa dalam menggunakan promo diskon ataupun cashback yang ada di aplikasi membuat pembayaran entah itu makan, minuman, berbelanja dan sebagainya menjadi lebih murah. Biasanya kaum milenial sangat berminat dengan adanya promo ataupun cashback karena sesuai dengan kantong mereka.

Faktor kedua, praktis,mudah dan waktunya bisa kapan saja dalam melakukan pembayaran. Era serba digital teknologi memudahkan kita dalam melakukan berbagai hal salah satunya ialah dalam melakukan transaksi pembayaran. Dompet digital terutama OVO memberikan pelayanan dengan kemudahan penggunanya dalam melakukan pembayaran melalui smartphone mereka. Pengguna hanya perlu terhubung dengan koneksi internet untuk menggunakan aplikasi OVO dan memiliki saldo di akun masing-masing. Begitu juga dengan penggunakan aplikasi shoppe kapanpun bisa belanja dengan pilihan barang-barang yang lengkap.

Menurut mereka mengguna ovo dan shopeepay sebagai dompet digital sangat terbantu sekali dalam melakukan pembayaran. Pengguna tidak perlu repot lagi dalam

pembayaran yang dimana jumlah uang yang dikeluarkan bisa sesuai dengan tarif produk yang di inginkan juga pengguna cukup melakukan scan barcode yang sudah disediakan oleh outlet untuk melakukan pembayaran, sehingga tidak perlu ribet untuk mengeluarkan uang dalam dompet.

Faktor ketiga adalah dorongan atau ajakan. Salah satu faktor yang mempengaruhi mereka dalam menggunakan aplikasi ovo ialah orang terdekat mereka bisa orang tua, kakak, teman, maupun lingkungan sekitarnya. Motif mereka menggunakan ovo karena ajakan tentunya telah diberikan penjelasan dari teman, orang tua, kakak, saudara mengenai aplikasi ovo yang dimana bisa digunakan untuk melakukan pembayaran, melakukan transfer uang, serta promo menarik untuk menghemat biaya dalam melakukan transaksi layanan transportasi online ataupun memesan makanan/minuman.

Saat situasi Pandemi COVID-19 pembentukan identitas diri mahasiswa Institut Agama Islam Nusantara yang juga pada konsep mind atau pikiran mempertimbangkan untuk bertransaksi mengunakan dompet digital dibandingkan dengan uang tunai. Hal ini merasa khawatir terhadap penularan COVID-19 dari transaksi secara langsung. Namun konsep mind atau pikiran manusia tentunya memiliki dua pilihan dalam tindakannya. Ketika mereka tidak memiliki saldo dalam akun OVO atau kondisi yang tidak memungkinkan seperti tidak bisa membayar lewat OVO terpaksa menggunakan uang cash dan mengikuti standar protokol yang sudah ada yaitu dengan mencuci tangan

Konsep kedua dari interaksi self atau diri. Pengguna Aplikasi OVO memikirkan setiap tindakan dan sikap yang dilakukannya dalam memanfaatkan Aplikasi OVO dalam kondisi COVID-19. Pengguna OVO di kalangan mahasiswa Institut Agama Islam Nusantara, sering memandang diri mereka dengan cara orang lain memandang diri mereka. Artinya bahwa sesuai dengan konsep diri yang kemudian akan menuntun pengguna aplikasi OVO membentuk konsep dirinya dalam dunia cyber.

Mereka akan belajar mengenal gambaran diri mereka melalui interaksi dengan individu yang ada disekitarnya. Begitu pula dalam menggunakan aplikasi OVO, mereka dalam menggunakan dompet digital OVO akan mengenal gambaran diri mereka melalui interaksi transaksi yang dilakukan entah konsumtif yang berlebihan atau biasa saja. Dalam kondisi pandemi COVID - 19 ini pula memberikan efek yang meningkat pula terhadap kegiatan transaksi menggunakan aplikasi OVO. Beberapa 
diantaranya beranggapan bahwa ketika menggunakan Aplikasi OVO lebih aman ketimbang uang tunai karena kecil kemungkinannya tertular virus. Hal tersebut menjadi pembentukan gambaran bahwa mereka dalam hal kehawatiran, kewaspadaan terutama terhadap penyakit Covid-19 baik itu meningkat daripada atau biasa saja.

Konsep ketiga adalah society atau masyarakat. Masyarakat terdiri atas perilaku yang saling bekerjasama diantara para anggotanya. Dalam fenomena ini, pengguna dompet digital OVO oleh mahasiswa Institus Agama Islam Nusantara Batanghari merupakan bagian masyarakat yang ada dalam dunia online. Interaksi yang diberikan antara kosumen (Mahasiswa) dan produsen (layanan jasa dan barang) berupa transaksi perdagangan yang dimaknai dalam kondisi pandemi COVID-19 sebagai dukungan atas pemutusan rantai penyebaran COVID- 19. Keadaan pandemi COVID-19 ini mempengaruhi antara konsumen dan produsen, menggambarkan sebuah konsep dalam teori ini. Peran aplikasi OVO dan Shopeepay dalam membentuk identitas diri Mahasiswa adalah sebagai wadah atau perangkat untuk memfasilitasi mahasiswa dalam mengkonstruksi diri dalam bertransaksi kepada produsen dengan mudah, dapat dilakukan kapan saja serta mencegah penularan COVID-19 tersebut.

\section{KESIMPULAN}

Berdasarkan hasil penelitian mengenai fenomena dompet digital pada generasi simpulan yang didapat diantaranya, pertama yakni memiliki motivasi dalam penggunaan aplikasi OVO yaitu pada shopping dan relaxation dimana Faktor shopping terdiri dari mendapatkan informasi tentang barang dan membeli produk yang diinginkan, sedangkan faktor relaxation terdiri dari memesan sesuatu lebih cepat, merasa lebih nyaman dan aman ketika bertransaksi, tidak merasa khawatir terhadap keuangan dan mempermudah pembayaran. Simpulan kedua; mind (pikiran), self (diri), society (masyarakat).
Konsep mind adalah pembentukan proses kegiatan mahasiswa untuk mempertimbangkan menggunakan transaksi nontunai selama pandemi Covid-19 dengan berpijak pada sebuah kebutuhan. Konsep self (diri); berhubungan dengan gambaran diri mahasiwa selama pandemi lebih ke arah perilaku gaya hidup baru menggunakan OVO maupun Shopeepay. Konsep society (masyarakat); mahasiswa sebagai bagian dari masyarakat melakukan transaksipembayaran melalui ovo maupun shopeepay sebagai bentuk interaksi yang baik untuk mengurangi resiko terinfeksi virus corona.

\section{DAFTAR PUSTAKA}

[1] Anonim. (2020). Cegah Penyebaran Virus Corona, Dorong Transaksi Nontunai, Ayo Pake QRIS ! Retrieved April 27, 2020, from https://www.jaringanprima.co.id/i $\mathrm{d} /$ cegah-penyebaran-virus-

corona dorong-transaksi- nontunaiayopake-qris

[2] Ardianto, E. (2007). Komunikasi Massa Suatu Pengantar. Bandung: Simbiosa Rekatama Media.

[3] Badan Pusat Statistik (BPS). (2018) Statistik Pemuda Indonesia. Jakarta: BPS.

[4] Bintarto, E. (2018). Fintech dan Cashless Society: Sebuah Revolusi Mendongkrak Ekonomi Kerakyatan. Call For Essays, $1-77$.

[5] Littlejohn, Stephen W. dan Karen A. Foss. (2009). Theories of Human

Communication, 9th ed. diterjemahkan dengan judul Teori Komunikasi, Edisi 9, Jakarta: Salemba Humanika.

[6] Nugraha, Aman Abadi dkk. (2018). Generasi Milenial: Inovasi dan Pembangunan Indonesia, Tangerang : Pustakapedia.

[7] Nurhidaya, (2020), Self Efficacy, Self Esteem, Dukungan Sosial, Fasilitas dan Pengaruhnya Dalam Meraih Prestasi Olahraga. Ponorogo: Senyum Indonesia. 
[8] Papalia, Diane. E., Selly Wendkos Olds., Ruth Duskin Feldemn., (2008). Human Development, Perkembangan Manusia, diterjemahkan oleh Brian Marswendy. Jakarta : Salemba Humanika.

[9] Phillips, David \& Philip Young. (2009). Online Public Relations: A Practical Guide To Developing An online Strategy In The World Of Social Media, Second Edition, London: Kogan Page Limited, United Kingdom.

[10] Prama, N. (2020). GoPay Ternyata Jadi

Dompet Digital Paling Diminati Generasi $Z$ dan Milenial.

[11] Rahadi, Dedi Rianto. (2017). Perilaku Pengguna dan Informasi Hoax di Media Sosial. Jurnal Manajemen dan Kewirausahaan.

[12] Rif'ah, S. (2019). Fenomena Cashless Society Di Era Milenial

Dalam Perspektif. Al-Musthofa: Journal of Sharia Economics

[13] Schunk, Dale H, Paul L. Pintrich, Judit, L, Meece., 2012, Motivation in Education: Theory, Research, and Appalication, diterjemahkan oleh Ellys Tjo dengan judul, Motivasi Dalam Pendidikan, Teori, Penelitian, dan Aplikasi, Jakarta : Indeks.

[14] Yuswohady. (2016). Millennial Trends 2016. Retrieved from https://www.yuswohady.com/ 